\title{
11-Konuşma eğitimi açısından Türkçe öğretmeni adaylarının ikna edici konuşmalarında kullandıkları ikna teknikleri ${ }^{1}$
}

Elif AKTAŞ2

\begin{abstract}
APA: Aktaş, E. (2020). Konuşma eğitimi açısından Türkçe öğretmeni adaylarının ikna edici konuşmalarında kullandıkları ikna teknikleri. RumeliDE Dil ve Edebiyat Araştırmaları Dergisi, (21), 180-197. DOI: 10.29000/rumelide.839173.
\end{abstract}

\section{$\ddot{\mathbf{O} z}$}

Türkçe dersinin öğrenme alanlarından biri olan konuşma; bireyin duygu, düşünce ve isteklerini anlaşılır bir biçimde sözlü olarak ifade etmesidir. Bu çalışmada, konuşma eğitimi etkinlikleri çerçevesinde Türkçe öğretmeni adaylarının hazırlayıp sundukları ikna edici konuşmalar, ikna teknikleri açısından incelenmiştir. Çalışmada, nitel araştırma yöntemlerinden doküman analizi kullanılmıştır. Katılımcıların belirlenmesinde kolay ulaşılabilir durum örneklemesi tercih edilmiştir. Buna göre, araştırmanın katılımcıları Akdeniz'de bir üniversitenin eğitim fakültesinin Türkçe Eğitimi Ana Bilim Dalı'nda öğrenim gören 38 Türkçe öğretmeni adayından oluşmaktadır. Verilerin toplanmasında araştırmacı tarafından geliştirilen ve ilgili literatür taranarak hazırlanan ‘İkna Edici Konuşma Gözlem Formu’ kullanılmıştır. Veriler, gerekli izinler alındıktan sonra araştırmacı tarafından 4 hafta boyunca yürütülen konuşma etkinlikleri çerçevesinde elde edilmiştir. Buna göre öğretmen adaylarının hazırladıkları metinler; ses kayıt cihazıyla kaydedilmiş, ardından yazıya geçirilmiştir. Verilerin analizinde ise nitel araştırma analiz tekniklerinden betimsel analiz kullanılmıştır. Araştırmanın bulgularına göre, öğretmen adaylarının ikna edici konuşmanın basamaklarından dikkat çekme ile inandırma kategorilerinde diğer iki kategoriye göre yetersiz oldukları tespit edilmiştir. Öğretmen adayları anlamayı sağlama ile tekrarlama/isteneni açılama basamaklarında ise daha başarılı olmuşlardır. Bu doğrultuda öğretmen adaylarının hedef kitlenin yaş, eğitim ve cinsiyet özelliklerine uygun bir konuşma tasarlamada kısmen başarısız oldukları ifade edilebilir.

Anahtar kelimeler: Türkçe öğretimi, konuşma eğitimi, ikna edici konuşma, Türkçe öğretmeni adayları

\section{Persuasion techniques used by Turkish teacher candidates in their persuasive speeches in terms of speaking education.}

Speaking one of the learning areas of Turkish lesson is verbal expression of an individual's feelings and thoughts. In this study, the persuasive speeches prepared by Turkish teacher candidates were analyzed in terms of persuasion techniques. Document analysis, one of the qualitative research methods, was used in the study. Convenience sampling was preferred in determining the participants. Participants of the study consist of 38 Turkish teacher candidates studying in the Department of Turkish Education of a university education faculty in the Mediterranean. "Persuasive Speech Observation Form" developed by the researcher was used in collecting the data. The data was obtained within the scope of speech activities conducted by the researcher for 4 weeks

Bu çalışma, 03-05 Ekim 2019 tarihleri arasında İzmir'de düzenlenen 12. Uluslararası Türkçenin Eğitimi-Öğretimi Kurultayı'nda sunulan sözlü bildirinin revize edilmiş ve güncellenmiş hâlidir.

Doc. Dr., Alanya Alaaddin Keykubat Üniversitesi, Eğitim Fakültesi, Türkçe ve Sosyal Bilimler Eğitimi Bölümü, Türkce Eğitimi ABD (Antalya, Türkiye), elif.aktas@alanya.edu.tr, ORCID ID: oooo-ooo1-5573-2274 [Araştırma makalesi, Makale kayıt tarihi: 17.11.2020-kabul tarihi: 20.12.2020; DOI: 10.2900o/rumelide.839173]

Adres
Address

Istanbul Medeniyet University, Faculty of Education Sciences,

Turkish and Social Scinces Education, Turkish Language Teaching

Education, Cevizli Campus, Kartal-İstanbul /TURKEY

e-mail: editor@rumelide.com 
after obtaining the necessary permissions. Accordingly, the texts prepared by teacher candidates; recorded with a voice recorder and then transcribed. Descriptive analysis, one of the qualitative research analysis techniques, was used in analyzing the data. According to the findings of the study, it was determined that the teacher candidates were insufficient in the categories of attention and persuasion. The preservice teachers were more successful in providing understanding and repeating / explaining what is wanted.

Keywords: Turkish teaching, speaking education, persuasive speaking, Turkish language teacher candidates

\section{Giriş}

Toplumsal bir varlık olan insan, diğer insanları anlayabilmek ve kendini anlatabilmek için sürekli iletişim içindedir. İnsanın içinde yaşadığı toplumun kültürünü, inançlarını, değerlerini ve kurallarını öğrenmesi, içselleştirmesi ve bunları gelecek kuşaklara aktararak neslini devam ettirmesi ancak iletişimle olur. Etkili konuşma ve dinleme becerileri, iletişim sürecini başarıyla yürütmek açısından son derece önemlidir.

Toplumsal bir varlık olan insanoğlu, bilgi vermek; bilgi almak, duygu ve düşüncelerini, istek ve ihtiyaçlarını dile getirmek ya da başkasının his ve fikirlerini öğrenmeye çalışmak için iletişim kurar (Yüksel, 2019: 145). Günümüz toplumlarında eğitim anlayışı; ifade becerisi gelişmiş, sosyal becerisi yüksek, yaratıcı düşünebilen, kişilerarası iletişimde başarılı ve problem çözebilen bireyler yetiştirmek üzerine odaklanmıştır. Eğitim, tüm hayatımız boyunca devam eden bir süreç olmakla birlikte bireyde istendik, kasıtlı ve bilinçli bir davranış değişikliği meydana getirmek olarak tarif edilmektedir (Senemoğlu, 1997: 7). Dolayısıyla eğitim, temelde bir iletişim kurma sürecidir. Öğrenme-öğretme ortamı içerisinde iletişim, "davranış değişikliği meydana getirmek üzere düşünce, bilgi, duygu, tutum ve becerilerin paylaşılması" şeklinde tanımlanmaktadır (Ergin ve Birol, 2000: 5).

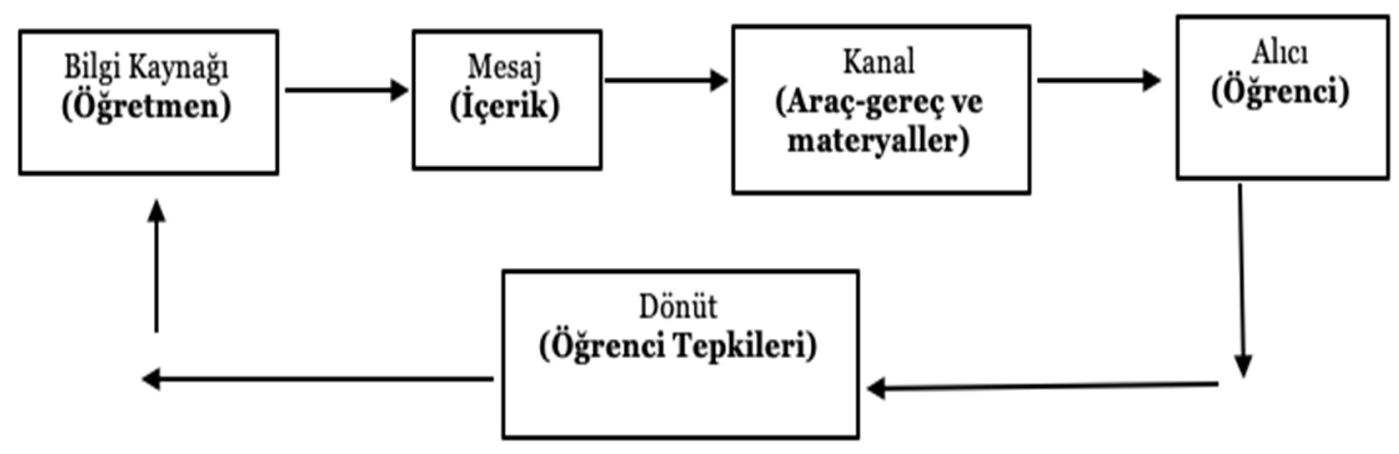

Şekil 1. Öğrenme-Öğretme ve İletişim Süreci

Şekil 1'de iletişim sürecinin temel ögeleri, öğrenme-öğretme ortamına uyarlanmıştır (Ergin ve Birol, 2000). Buna göre, sınıf ortamında tek yönlü bir bilgi aktarımından bahsetmek mümkün değildir. Bunun iletişim değil, iletim/iletme olduğunu söylemek mümkündür. Tek yönlü bilgi aktarımına dayalı bir öğrenme ortamında öğrenmelerin kalıcı olduğundan da bahsedilemez. Dolayısıyla iletişim sürecinin ögelerinden herhangi biri olmadan iletişimden bahsetmek doğru değildir. Öğrenme-öğretme sürecinde okul içi ya da okul dışı etkinliklerde iletişim sürecini başlatan kişi çoğunlukla öğretmendir.

\footnotetext{
\begin{tabular}{r|l} 
Adres & Address \\
İstanbul Medeniyet Üniversitesi, Eğitim Bilimleri Fakültesi, Türkçe & İstanbul Medeniyet University, Faculty of Education Sciences,
\end{tabular} ve Sosyal Bilimler Eğitimi Bölümü, Türkçe Eğitimi ABD Cevizli $\quad$ Turkish and Social Scinces Education, Turkish Language Teaching Kampüsü, Kartal-İstanbul/TÜRKIYE $\quad$ Education, Cevizli Campus, Kartal-İstanbul /TURKEY e-posta: editor@rumelide.com $\mid$ e-mail: editor@rumelide.com
} 
Öğretmen, iletişim sürecini başlatarak, öğrenciye rehberlik ederek ve süreç içerisinde aktif rol oynayarak öğrenmeyi gerçekleştirir. Sınıf içinde öğretmen, temel olarak öğrencilerini etkilemek ve onları ikna etmek için iletişim kurmaktadır. Çünkü iletişim kurmanın temelinde çoğunlukla karşıdaki kişiyi ikna etmek yatar. Bu açıdan öğretmenin iletişim ve ikna becerileri ne kadar yüksek olursa eğitimde belirlenen hedeflere ulaşmak o kadar kolay olacaktır. Bu nedenle iletişim sürecini başlatan kaynak konumunda olan öğretmenlerin etkili bir iletişim becerisine sahip olması gerekmektedir. Bu beceri hayatın her alanında kişiye önemli katkılar sağlayan bir beceridir.

Davranış değişikliği meydana getirmek maksadıyla bilgi, duygu, düşünce, tutum ve becerilerin paylaşılması sürecine iletişim denmektedir (Ergin ve Birol, 2000: 25). Kişinin kendisiyle olan iletişiminden diğer insanlarla olan iletişimine, kitle iletişiminden sözsüz iletişime kadar çok geniş bir kavramı içine alan iletişim; mesaj üretme, iletme ve anlamlandırma aşamalarından oluşur (Dökmen, 1995: 19). İletişim kurmaktaki asıl amaç, gönderilen mesajlar yoluyla alıcının tutum ve davranışlarında değişiklik meydana getirmektir (Tutar ve Yılmaz, 2003: 5). İletişimin yeni tutum geliştirmek, var olan tutumun şiddetini artırmak ya da değiştirmek gibi üç farklı amacı ve sonucu vardır (Kağıtçıbaşı, 2005: 180; Mutlu, 1994: 185). Bu tanım ve açıklamalar, iletişimin bir ikna süreci olduğunu ortaya koymaktadır.

İkna yoluyla kurulan iletişimde başkalarının düşünce, davranış ve tutumları değiştirilir; geliştirilir veya kişiye yeni düşünce, davranış ve tutumlar kazandırılır. İkna, temelde insanları daha önce bilmedikleri veya paylaşmadıkları bir görüşe yakınlaşmalarını sağlar. Pek çok iletişimde insanlar, karşısındaki bireylerin davranış ve tutumlarını değiştirmesi için onu ikna etmeyi amaçlamaktadır (Yüksel, 1994: 3). Böylelikle ikna, bir öğrenme süreci hâline gelir. Bazı araştırmalar iknayı bir öğrenme şekli olarak da tanımlar (Yüksel, 1994: 74). İletişimde asıl amaç insanlara yeni davranış kazandırma ve onların davranışlarını değiştirme olduğunda öğrenme ve ikna aynı paydada buluşmaktadır. Çünkü öğrenme ve ikna bireyin tutum, inanç ve davranışlarında farklı yollarla değişiklik yaratır.

"İkna kelimelerle, görsellerle, çeşitli yöntem, teknik ve stratejilerle insanlarm inançların, düşüncelerini, davranışlarmı, motivasyonlarm, arzu ve isteklerini etkilemektir.” (Kurudayığlu ve Yılmaz, 2013: 82). İkna edici konuşma; birtakım sözel çabalarla dinleyicileri harekete geçirme, onlarda istendik değişimler ortaya çıkarmadır. İkna edici konuşmada şu amaç ve sonuçlardan bahsetmek mümkündür:

- Mevcut tutumun pekişmesi,

- Mevcut tutumun değişmesi,

- Yeni tutum meydana gelmesi,

- Davranışın değişmesi (Yüksel, 2019: 126).

İnsanları yönlendirmek ve onların düşüncelerini, inançlarını, tutumlarını, davranışlarını istendik yönde değiş̧irmek için en sık kullanılan teknik, ikna etme tekniğidir. Türkçe Sözlük’te (TDK, 2011) "Bir konuda birinin inanmasını sağlama, inandırma, kandırma" şeklinde tanımlanan ikna; inançları, tutumları, niyetleri ve hatta davranışları değiştirmeye yönelik bir iletişim sürecidir (Deniz, 2007: 13). İkna, insanları belli teknik ve stratejilerle etkileme, inançları ve değerleri kabullendirme yeteneğidir (Hogan, 2007: 20). Eğitimde ikna tekniklerinin kullanım amacı, belirlenen hedefler doğrultusunda

Adres

İstanbul Medeniyet Üniversitesi, Eğitim Bilimleri Fakültesi, Türkçe ve Sosyal Bilimler Eğitimi Bölümü, Türkçe Eğitimi ABD Cevizli Kampüsü, Kartal-İstanbul/TÜRKIYE e-posta: editor@rumelide.com 
öğrencileri yönlendirmektir. İkna tekniklerini kullanan öğretmen, eğitimin amaçlarına ulaşmada daha başarılı olur.

Türkçe dersinin öğrenme alanlarından biri olan konuşma; bireyin duygu, düşünce ve isteklerini anlaşılır bir biçimde sözlü olarak ifade etmesidir. Sözlü iletişimin temelinde konuşma ve dinleme becerileri vardır. Konuşma ve dinleme becerisi, okuma ve yazma becerisi kadar önemlidir ve eğitimle geliştirilebilir. Türkçe dersleri, temel eğitimden itibaren konuşma eğitimi etkinlikleri kapsamında öğrencilerin ikna becerilerini de geliştirmeye odaklanmaktadır. Nitekim ikna edici konuşma, Türkçe Dersi Öğretim Programı'nda (MEB, 2009) “dikkat çekme, anlamayı sağlama, inandırma, tekrarlama ve istenileni açıklama” basamaklarından oluşan bir konuşma stratejisi /tekniği olarak tanımlanmıştır.

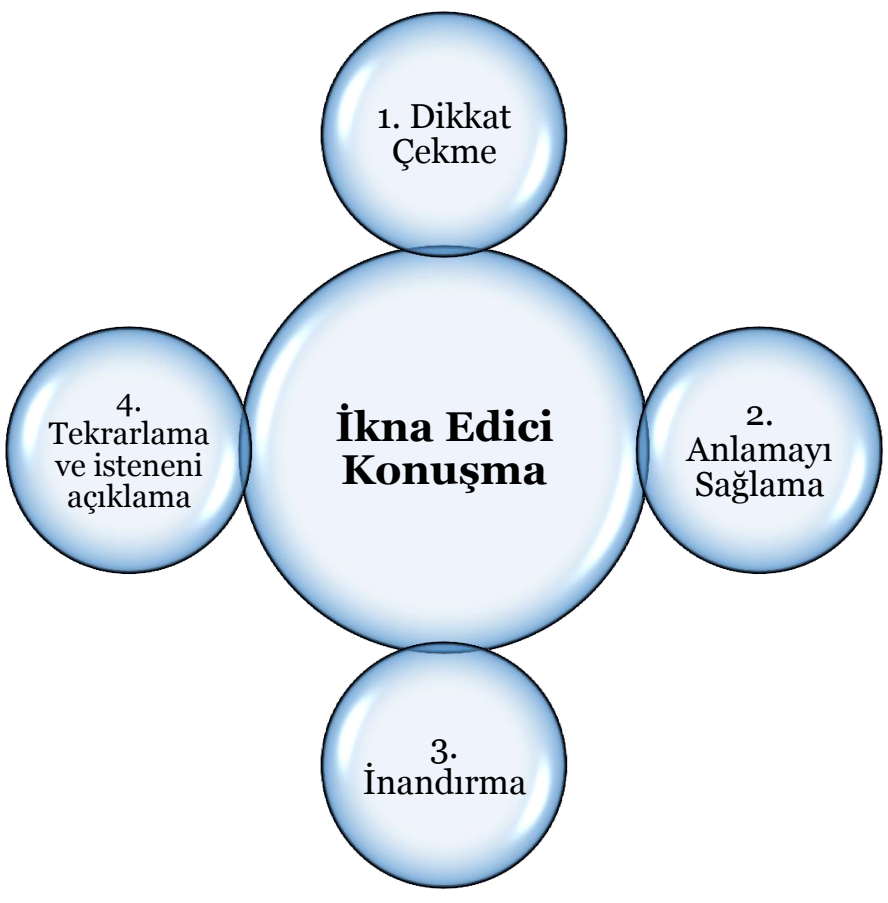

Şekil 2. İkna edici konuşmanın basamakları

Şekil 2'ye göre ikna edici konuşmanın dört temel unsuru vardır (MEB, 2009). Bunlardan ilki dikkat çekmedir. Bir konuşmaya başlamadan önce dikkat çekmek, dinleyicinin konuya ilgi duymasını sağlayacağı gibi konuşmanın gidişatını da etkilemektedir. İkna edici konuşmanın başarıya ulaşması, giriş ve sonuç bölümlerinin başarısına bağlıdır. İyi seçilmiş ve yapılandırılmış dikkat çekme etkinlikleri, dinleyicinin konuşmaya olan ilgisini de uyandırmış olacaktır. Giriş bölümünün dört amacı vardır: dikkati toplama, sesin tonunu ayarlama, iyi niyet yaratma ve içeriğe yöneltme. Buna göre dikkat çekme kapsamında örnekler verme, soru sorma, içerikten haberdar etme, müzikten, görsellerden ve teknolojik gereçlerden faydalanma, ses tonunu, jest, mimik ve beden dilini etkin kullanma, anekdot/fikra/hikâye vb. anlatma gibi etkinliklerden faydalanılabilir. Bunun yanı sıra ikna edici konuşmalarda kullanılan tipik giriş türleri; şaşırtıcı ifadeler kullanmak, soru sormak, hikâye anlatmak, örnek vermek, kişisel atıflar ve alıntı yapmak, şüphe uyandırmaktır (Yüksel, 2019, 167; MEB, 2019).

İkna edici konuşmanın ikinci basamağı ise anlamayı sağlamadır. Bu aşamada canlı bir dil ve somut örneklerle konunun anlaşılması sağlanır. Dinleyicinin ikna olabilmesi için her şeyden önce 
konuşmacıyı anlaması gerekir. Bu aşamada; ön bilgileri harekete geçirme, açı ve net bir dil kullanma, karşısındakini konuşmaya dâhil etme, yazı tahtası kullanma, slogan kullanma, birden çok duyu organına hitap etme gibi strateji ve etkinliklerden faydalanılabilir.

İkna edici konuşmanın asıl can alıcı noktası inandırmadır. Bu aşamada konuşmacı her şeyden önce dinleyicinin soru ve kuşkularını giderecek kanıtlar sunarak onu inandırmaya çalışmalıdır. Bunun yanı sira empati kurma, ses tonunu etkin kullanma, vurgu ve tonlamaya özen gösterme, hedef kitleye saygı duyma ve bunu gösterme, düşünceyi geliştirme tekniklerinden faydalanma (sayısal verilerden faydalanma, tanık gösterme/alıntı yapma, karşılaştırma, örnekler verme vb.), abartılı açıklama yapma/söz sanatları kullanma, mekânı etkin kullanma, olumlu sözcükler kullanma/pozitif olma, materyal kullanma, içten bir üslup kullanma, zıt fikirler sunma ve bunları çürütme, farklı çözüm önerileri sunma, mantıklı, nesnel argümanlar kullanma, jest, mimik ve beden dilini etkin kullanma vb. teknik ve stratejilerden faydalanılabilir.

Şekil 2'ye göre ikna edici bir konuşmanın son basamağı tekrarlama ve isteneni açıklamadır. Bu aşamada ana fikir aralıklarla tekrar edilir ve özet yapılır. Konuşmacı; ikna etmenin son basamağında net ve kesin ifadeler kullanarak, mesajı ve anahtar kelimeleri tekrarlayarak, özet yaparak dinleyiciyi etkilemeye çalışır. Konuşmanın sonuç bölümü konuşmacının amacına ulaşması için son şanstır. Bu aşamada özet, hikâye, harekete yöneltme ve duygusal etki kullanılabilir (Yüksel, 2019: 167; MEB, 2019). İkna edici konuşmalarda amaca ulaşma, istendik değişimleri ortaya çıkarma, iyi düzenlenmiş, bir giriş ve sonuç bölümü ile sağlanabilir. İletişim süreci sonrasında her zaman akılda kalan son söylenendir, bu nedenle kötü başlayan bir konuşma, sonuç bölümünün etkili bir şekilde tasarlanmasıyla başarıya ulaşabilir.

Türkçe dersi öğretim programlarında ikna ediciliğe bir metin türü olarak gereken önemin verilmediği dikkat çekmektedir. 2005 Türkçe Dersi Öğretim Programı ve Kılavuzu'nda (1-5. Sinıflar) ikna ediciliğin bir metin türü olarak ele alınmadığı ve üçüncü sınıftan itibaren "İkna edici konuşmalar yapar." şeklinde bir kazanıma yer verdiği görülmektedir. 2019 programında ise ikna edici konuşma, yalnızca bir konuşma stratejisi olarak sekizinci sınıf düzeyinde karşımıza çıkmaktadır. Konuşma becerisinin ilköğretimden itibaren geliştirilmesi büyük önem arz etmektedir. Öğrencilerin ikna edici konuşma becerilerinin geliştirilmesi için onlara birtakım bilgiler kazandırılmalı, konuşma etkinlikleri yaptırılmalı, örnekler üzerinden tartışma ve analizler yapılmalıdır. Öğrenme-öğretme sürecinin başarılı bir şekilde yürütülebilmesi için sınıf ortamında iletişimin sağllklı ve etkili yürütülmesi gerekmektedir. Öğretmen ve öğrenci arasında etkili bir iletişimdeki en büyük pay, öğretmene aittir.

Öğretmenler, icra ettikleri meslek gereği kişilerarası iletişimde başarılı olmak zorundalardır. Çünkü onlar, davranış değiştirme sürecinde karşısındakini ikna etmeye çalışmaktadırlar. Bu da iyi bir dil ve iletişim becerisine sahip olmayı gerektirmektedir. Öğretmen; iletişim sürecini başlatarak, bu süreçte öğrencilerine rehberlik yaparak, aktif rol oynayarak öğrenmenin gerçekleşmesini sağlar. Öğrenmeöğretme faaliyetleri, her şeyden önce iletişime dayalıdır. Dolayısıyla öğretmenin etkili iletişim becerilerine sahip olması bu açıdan önemlidir. İkna ile karşıdakinin düşünce, tutum ve davranışları değiştirilir. Bu nedenle öğretmenlerin iletişim becerileri kadar ikna kabiliyetlerinin de yüksek olması gerekmektedir. Öğretmenlerin ikna edici iletişim becerilerinin geliştirilmesi için uygulamalı eğitim verilmesi eğitim faaliyetlerinin hedeflerine ulaşılması açısından yararlı olacaktır (Türkkan, 2000: 18).

İlgili literatür incelendiğinde öğretmen adaylarının konuşmalarında kullandıkları ikna tekniklerini tespit etmeyi amaçlayan bir çalışmaya rastlanmamıştır. Ĕ̆itimde ikna tekniklerinin kullanımına ilişkin

\footnotetext{
Adres $\mid$ Address

İstanbul Medeniyet Üniversitesi, Eğitim Bilimleri Fakültesi, Türkçe İstanbul Medeniyet University, Faculty of Education Sciences, ve Sosyal Bilimler Eğitimi Bölümü, Türkce Eğitimi ABD Cevizli Turkish and Social Scinces Education, Turkish Language Teaching Kampüsü, Kartal-İstanbul/TÜRKIYE $\quad$ Education, Cevizli Campus, Kartal-İstanbul /TURKEY e-posta: editor@rumelide.com 1 e-mail: editor@rumelide.com
} 
çalışmalar, yazma becerisi üzerinde odaklanmıştır. Yapılan araştırmalar, farklı yaş ve seviyelerde olan öğrencilerin ikna edici metin yazma becerilerini incelemeye yöneliktir (Kurudayığlu ve Yllmaz, 2013; Kaptan, 2015; Kan ve Erbaş, 2017; Esmer, 2018; Beyreli ve Konuk, 2018). Bunun yanı sıra Okur, Süğümlü ve Göçen (2013) ikna edici metin türünün Türkçe Öğretim Programlarında ve ders kitaplarında yeteri kadar yer almadığını, bu durumun da öğretimde eksikliklere neden olduğunu söylemektedir. Bu çalışma, söz konusu alandaki boşluğu doldurmayı amaçlayarak ikna edici konuşma becerisi üzerinde odaklanmıştır.

$\mathrm{Bu}$ çalışmanın amacı, Türkçe öğretmeni adaylarının ikna edici konuşmalarında kullandıkları ikna tekniklerini incelemek ve bu tekniklerin cinsiyete göre dağılımını tespit etmektir. Bu amaçla çalışmada, konuşma eğitimi etkinlikleri çerçevesinde Türkçe öğretmeni adaylarının hazırlayıp sundukları ikna edici konuşmalar, ikna teknikleri açısından incelenmeye çalışılmıştır. Bu amaçla aşağıdaki alt problemlere yanıt aranmıştır:

1 Türkçe öğretmeni adaylarının kullandıkları ikna tekniklerinin genel olarak dağılımı nasıldır?

2 Türkçe öğretmeni adaylarının 'dikkat çekme' basamağında kullandıkları ikna tekniklerinin cinsiyete göre dağılımı nasıldır?

3 Türkçe öğretmeni adaylarının 'anlamayı sağlama' basamağında kullandıkları ikna tekniklerinin cinsiyete göre dağılımı nasıldır?

4 Türkçe öğretmeni adaylarının 'inandırma' basamağında kullandıkları ikna tekniklerinin cinsiyete göre dağılımı nasıldır?

5 Türkçe öğretmeni adaylarının 'tekrarlama ve isteneni açıklama' basamağında kullandıkları ikna tekniklerinin cinsiyete göre dağılımı nasıldır?

\section{Yöntem}

Türkçe öğretmeni adaylarının ikna edici konuşmalarında kullandıkları ikna tekniklerini incelemeyi amaçlayan bu çalışma, betimleyici bir nitel araştırma özelliği göstermektedir. Nitel araştırmalar; gözlem, görüşme ve doküman analizi gibi nitel veri toplama yöntemlerinin kullanıldığı, algıların ve olayların doğal oramda gerçekçi ve bütüncül bir biçimde ortaya konmasına yönelik nitel bir sürecin izlendiği araştırmalardır (Yıldırım ve Şimşek, 2016). Çalışmada nitel araştırma yöntemlerinden araştırılması hedeflenen olgu ve olgular hakkında bilgi içeren yazılı materyallerin analizini kapsayan doküman incelemesi yöntemi kullanılmıştır (Yıldırım ve Şimşek, 2016). Buna göre araştırmada Türkçe öğretmeni adaylarının ikna edici konuşmalarında kullandıkları ikna teknikleri doküman incelemesi yöntemiyle incelenmiştir.

\section{Araştırmanın katılımcıları}

Katılımcıların belirlenmesinde araştırmacıya hız ve pratiklik kazandıran kolay ulaşlabilir durum örneklemesi tercih edilmiştir. Buna göre, araştırmanın katılımcıları Akdeniz'de bulunan bir üniversitenin eğitim fakültesinde öğrenim öğren 38 Türkçe öğretmeni adayından oluşmaktadır. 20192020 eğitim-öğretim yllında birinci sınıfta öğrenim gören 38 Türkçe öğretmeni adayının 22'si kadın, 16'sı erkektir. Örnekleme ait demografik özellikler Tablo 1'de sunulmuştur:

\footnotetext{
Adres $\mid$ Address

İstanbul Medeniyet Üniversitesi, Eğitim Bilimleri Fakültesi, Türkçe İstanbul Medeniyet University, Faculty of Education Sciences, ve Sosyal Bilimler Eğitimi Bölümü, Türkçe Eğitimi ABD Cevizli Turkish and Social Scinces Education, Turkish Language Teaching Kampüsü, Kartal-İstanbul/TÜRKIYE $\quad$ Education, Cevizli Campus, Kartal-İstanbul /TURKEY e-posta: editor@rumelide.com 1 e-mail: editor@rumelide.com
} 


\begin{tabular}{l|l|l}
\hline Cinsiyet & f & \% \\
\hline Kadın & 22 & 57,89 \\
\hline Erkek & 16 & 42,1 \\
\hline Toplam & $\mathbf{3 8}$ & \\
\hline
\end{tabular}

Tablo 1: Araştırma grubunun demografik özellikleri

\section{Veri toplanması ve analizi}

Verilerin toplanmasında araştırmacı tarafından geliştirilen ve ilgili literatür taranarak hazırlanan ‘íkna Edici Konuşma Gözlem Formu' kullanılmıştır. Forma son şeklinin verilmesinde Türkçe eğitimi alan uzmanlarının ( $\mathrm{n}=3)$ görüşlerinden faydalanılmıştır. Formda öğretmen adaylarının yaptıkları konuşma metinlerini değerlendirmeye yönelik dört ana kategoriye yer verilmiştir: dikkat çekme, anlamayı sağlama, inandırma, tekrarlama ve istenileni açıllama.

Formda yer alan bu ana kategorilerin belirlenmesinde 2009 Türkçe Dersi öğretim Programı ve Kılavuzu esas alınmıştır. Söz konusu programın açıklamalar kısmında ikna edici konuşmanın yukarıda belirtilen dört ana boyutu yer almaktadır. Alt kategorilerin belirlenmesinde ise Deniz'in (2007), Hogan (2007) ile Hogan ve Speakman'dan (2007) derleyerek oluşturduğu ikna teknikleri listesinden faydalanılmıştır. Veriler toplanmadan önce etik kurul izni için gerekli başvurular yapılmış ve izin belgesi 01/06/2020 toplantı tarihi ve 2020/04 karar sayısı ile Alanya Alaaddin Keykubat Üniversitesi Bilimsel Araştırma ve Yayın Etiği Kurulu tarafından verilmiştir.

Veri toplama sürecinde, İkna Edici Konuşma Gözlem Formu, her bir öğretmen adayı için ayrı ayrı doldurulmuştur. Ayrıca öğretmen adaylarının konuşmalarında hangi ikna tekniklerini kullandıklarını belirlemeden önce onlara ikna teknikleri hakkında bilgiler verilip uygulama örnekleri yaptırılmıştır. Veriler, araştırmacının kendisi tarafından yürütülen etkinlikler çerçevesinde elde edilmiștir. Her bir öğretmen için 5-7 dk. konuşma süresi belirlenmiştir. Öğretmen adaylarının hazırladıkları konuşma metinleri, ses kayıt cihazıyla kaydedilmiş, ardından veriler analiz için yazıya geçirilmiştir.

Konu seçimine öğretmen adayları ve öğretim elemanı birlikte karar vermiş, ikna edici konuşma niteliği taşımayan ve din, dil, ırk, siyaset, cinsiyet ayrımcılı̆̆ı içeren konular kapsam dışı bırakılmıştır. Öğretmen adaylarının ikna edici konuşma yaptıkları bazı konu örnekleri aşağıda verilmiştir:

Çok okuyan mı yoksa çok gezen mi bilir? Bir de benden dinleyin.

Organ bağışı niçin önemlidir?

Başarıya ulaşmada zekâ mı çalışmak mı önemlidir?

Pedagojik formasyon eğitimi kaldırılmalıdır.

Harf devrimi neden gerekliydi?

Siverek neden il olmalıdır?

Burçlara inanır mısınız? Burcunuzun insanı mısınız? Sahi burcunuz nedir?

Hayvan hakları niçin önemlidir?

Sabahları neden kahvaltı yapmalıyız?

Okullarda bitişik eğik yazı gerekli midir?

Okullarda serbest kıyafet uygulaması olmalı mıdır?

Okumak ve yazmak, okur-yazar olmak mıdır?

Adres

İstanbul Medeniyet Üniversitesi, Eğitim Bilimleri Fakültesi, Türkçe ve Sosyal Bilimler Eğitimi Bölümü, Türkce Eğitimi ABD Cevizli Kampüsü, Kartal-İstanbul/TÜRKIYY e-posta: editor@rumelide.com
Address

Istanbul Medeniyet University, Faculty of Education Sciences,

Turkish and Social Scinces Education, Turkish Language Teaching

Education, Cevizli Campus, Kartal-İstanbul /TURKEY

e-mail: editor@rumelide.com 
Neden yerli üretime geçmeliyiz?

Veri analizi, ham verilerin okuyucunun anlayabileceği ve gerek duyduğunda kullanabileceği bir şekle dönüştürülmesi anlamına gelen betimsel analiz tekniği kullanılarak yapılmıştır. Betimleyici analiz tekniklerinden yüzde ve frekans analizi ile çözümlenen veriler, önceden oluşturulan ana temalara göre sınıflandırılıp yorumlanmıştır. Ana temaların altında yer alan alt kategorilerin belirlenmesinde ise öğretmen adaylarının konuşma metinleri ve literatür taraması esas alınmıştır. Bu doğrultuda araştırmada öncelikle Türkçe öğretmeni adaylarının ikna edici konuşma metinlerindeki stratejiler tespit edilmiş; ardından bu stratejiler cinsiyet değişkenine göre sınıflandırılmıştır. Son olarak da her bir stratejiye yönelik frekans ve yüzde değerleri hesaplanarak sayısal veriler tablolaştırılmıştır.

\section{Geçerlik ve güvenirlik}

$\mathrm{Bu}$ araştırmada verilerin geçerliğinin sağlanması için analizci üçgenlemesi tekniği kullanılmıştır. Nitel araştırmalarda geçerliliği sağlamak için en çok bilinen ve uygulanan strateji, üçgenleme tekniğidir. Üçgenleme tekniği, iki veya daha fazla araştırmacının birbirlerinden bağımsız olarak analiz ettiği nitel bulguların karşılaştırılması olarak tanımlanan çoklu analizci kullanımıdır (Merriam, 2013). Yani iki veya daha fazla kişiye aynı nitel verinin bağımsız olarak analiz ettirilmesi ve bulguların karşılaştırılmasıdır (Patton, 2014). Bu kapsamda bulgular, araştırmacı dışında bir başka araştırmacı tarafından da incelenmiştir. İki araştırmacı tarafından bağımsız olarak analiz edilerek ulaşılan sonuçlar Miles ve Huberman'ın (1994) ortaya koyduğu güvenirlik formülü aracılığıyla hesaplanmıştır. Böylelikle \%98 çıkan uyuşum değeriyle araştırmanın güvenilir olduğunu görülmüştür. Uzlaşma göstermeyen veriler ise tartışlarak tekrar gözden geçirilip ortak karara varılmıştır. Böylelikle verilerin tamamında uzlaşma sağlanmıştır.

\section{Bulgular ve yorum}

Öğretmen adaylarının ikna edici konuşma metinlerindeki ikna teknikleri 4 ana kategori ve bu ana kategorilere bağlı alt kategoriler altında analiz edilmiş ve sonuçlar Tablo 2, 3, 4, 5 ve 6'da sunulmuştur.

\begin{tabular}{|c|c|c|c|c|}
\hline \multirow{3}{*}{ Ana kategoriler } & \multicolumn{4}{|c|}{ Cinsiyet } \\
\hline & \multicolumn{2}{|c|}{ Kadın } & \multicolumn{2}{|c|}{ Erkek } \\
\hline & $\mathbf{f}$ & $\%$ & $\mathbf{f}$ & $\%$ \\
\hline Dikkat çekme & 160 & 34,26 & 86 & 27,38 \\
\hline Anlamayı sağlama & 62 & 13,27 & 42 & 13,37 \\
\hline İnandırma & 194 & 41,54 & 146 & 46,49 \\
\hline Tekrarlama ve isteneni açıklama & 51 & 10,92 & 40 & 12,73 \\
\hline TOPLAM & 467 & & 314 & \\
\hline
\end{tabular}

Tablo 2: Öğretmen adaylarının kullandıkları ikna tekniklerinin genel dağılımı

Tablo 2'ye göre kadın öğretmen adayları tüm kategorilerde toplamda 467 strateji, erkek öğretmen adayları ise toplamda 314 strateji kullanmışlardır. Kadın adaylar lehine olan bu sayısal üstünlük, örneklem grubundaki kız öğrenci sayısının fazla oluşuna bağlanabilir. Alt kategoriler açısından

\footnotetext{
\begin{tabular}{r|l} 
Adres & Address \\
İstanbul Medeniyet Üniversitesi, Eğitim Bilimleri Fakültesi, Türkçe & İstanbul Medeniyet University, Faculty of Education Sciences,
\end{tabular} ve Sosyal Bilimler Eğitimi Bölümü, Türkce Eğitimi ABD Cevizli $\quad$ Turkish and Social Scinces Education, Turkish Language Teaching Kampüsü, Kartal-İstanbul/TÜRKIYE $\quad$ Education, Cevizli Campus, Kartal-İstanbul /TURKEY e-posta: editor@rumelide.com 1 e-mail: editor@rumelide.com
} 
Persuasion techniques used by Turkish teacher candidates in their persuasive speeches in terms of speaking education / E. Aktaş (pp. 180-197)

bakıldığında ise öğretmen adayları en çok ikna tekniğini dikkat çekme ve inandırma basamağında kullanmışlardır. Tekrarlama ve isteneni açıklama basamağında ise her iki cinsiyet de en az sayıda teknik kullanmıştır. Bu doğrultuda öğretmen adaylarının dikkat çekme ve inandırma basamaklarında her iki cinsiyet açısından daha başarılı oldukları, tekrarlama ve isteneni açıklama basamağında ise kısmen yetersiz oldukları ifade edilebilir. Ayrıca Tablo 2'ye göre tekrarlama ve isteneni açıklama kategorisi (kadın=\%10,92, erkek=\%12,73) dışında kadın öğretmen adaylarının erkeklerden diğer tüm kategorilerde daha fazla sayıda strateji kullandıkları dikkat çekmektedir.

\begin{tabular}{|c|c|c|c|c|}
\hline \multirow{3}{*}{$\begin{array}{l}\text { 'Dikkat Çekme' Basamağının } \\
\text { Alt Kategorileri }\end{array}$} & \multicolumn{4}{|c|}{ Cinsiyet } \\
\hline & \multicolumn{2}{|c|}{ Kadın } & \multicolumn{2}{|c|}{ Erkek } \\
\hline & $\mathbf{f}$ & $\%$ & $\mathbf{f}$ & $\%$ \\
\hline Örnek(ler) verme & 36 & 22,5 & 22 & 25,58 \\
\hline Ses tonunu etkin kullanma & 16 & 10 & 13 & 15,11 \\
\hline Soru sorma/merak uyandırma & 41 & 25,62 & 32 & 37,2 \\
\hline İçerikten haberdar etme & 21 & 13,12 & 15 & 17,44 \\
\hline Müzik unsurundan faydalanma & 5 & 3,12 & 2 & 2,32 \\
\hline Görsellerden faydalanma & 18 & 11,25 & 9 & 10,46 \\
\hline Teknolojiden faydalanma & 6 & 3,75 & 8 & 9,3 \\
\hline Anekdot/fikra/hikâye vb. kullanma & 5 & 3,12 & 2 & 2,32 \\
\hline Jest, mimik ve beden dilini kullanma & 12 & 7,5 & 15 & 17,44 \\
\hline TOPLAM & 160 & & 86 & \\
\hline
\end{tabular}

Tablo 3: Öğretmen adaylarının ‘dikkat çekme’ basamağında kullandıkları ikna tekniklerinin dağılımı

Tablo 3’e göre kadın öğretmen adayları tüm kategorilerde toplamda 160, erkek öğretmen adayları ise 86 strateji kullanmışlardır. Bu sayısal üstünlük, kadınların oranının erkeklerden daha fazla olmasıyla ilişkilendirilebilir.

Tablo 3 incelendiğinde öğretmen adaylarının dikkat çekme kategorisinde en fazla soru sorma ve örnek verme stratejilerini kullandıkları görülmektedir. Müzik unsurundan faydalanma ve anekdot, fikra, hikâye vb. kullanma stratejileri ise öğretmen adayları tarafından en az tercih edilen stratejilerdendir.

Tablo 3’e göre kadın öğretmen adayları en fazla sırasıyla soru sorma (\%25,62), örnekler verme $(\% 22,5)$ ve içerikten haberdar etme $(\% 13,12)$ stratejilerini; erkek öğretmen adayları ise sirasıyla en fazla soru sorma $(\% 37,2)$, örnekler verme $(\% 25,58)$, içerikten haberdar etme $(\% 17,44)$ ve jest, mimik, beden dili kullanma $(\% 17,44)$ stratejilerini tercih etmişlerdir. Kadın öğretmen adaylarının en az kullandıkları stratejiler ise sirasiyla anekdot/fikra/hikâye vb. kullanma $(\% 3,12)$, müzik unsurundan $(\% 3,12)$ ve teknolojiden faydalanma $(\% 3,75)$ stratejileridir. Erkek öğretmen adaylarının en az kullandıkları

\footnotetext{
Adres $\mid$ Address

İstanbul Medeniyet Üniversitesi, Eğitim Bilimleri Fakültesi, Türkçe İstanbul Medeniyet University, Faculty of Education Sciences, ve Sosyal Bilimler Eğitimi Bölümü, Türkce Eğitimi ABD Cevizli Turkish and Social Scinces Education, Turkish Language Teaching Kampüsü, Kartal-İstanbul/TÜRKIYE $\quad$ Education, Cevizli Campus, Kartal-İstanbul /TURKEY e-posta: editor@rumelide.com 1 e-mail: editor@rumelide.com
} 
stratejiler de sirasıyla anekdot/fikra/hikâye vb. kullanma $(\% 2,32)$ ve müzik unsurundan faydalanma $(\% 2,32)$ olmuştur.

\begin{tabular}{|c|c|c|c|c|}
\hline \multirow{3}{*}{$\begin{array}{l}\text { 'Anlamayı Sağlama' Basamağının } \\
\text { Alt Kategorileri }\end{array}$} & \multicolumn{4}{|c|}{ Cinsiyet } \\
\hline & \multicolumn{2}{|c|}{ Kadın } & \multicolumn{2}{|c|}{ Erkek } \\
\hline & $\mathbf{f}$ & $\%$ & $\mathbf{f}$ & $\%$ \\
\hline Ön bilgileri harekete geçirme & 14 & 22,58 & 10 & 23,80 \\
\hline Birden çok duyu organına hitap etme & 19 & 30,64 & 6 & 14,28 \\
\hline Açık, net ve seviyeye uygun bir dil kullanma & 13 & 20,96 & 15 & 35,71 \\
\hline Karşısındakini konuşmaya dâhil etme & 13 & 20,96 & 7 & 16,66 \\
\hline Yazı tahtasını kullanma & 2 & 3,22 & 4 & 9,52 \\
\hline Slogan kullanma & 1 & 1,61 & - & - \\
\hline TOPLAM & 62 & & 42 & \\
\hline
\end{tabular}

Tablo 4: Öğretmen adaylarının ‘anlamayı sağlama' basamağında kullandıkları ikna tekniklerinin dağılımı

Tablo 4'e göre kadın öğretmen adayları tüm kategorilerde toplamda 62, erkek öğretmen adayları ise 42 strateji kullanmışlardır. Bu sayısal üstünlük, kadınların oranının erkeklerden daha fazla olmasıyla açıklanabilir.

Tablo 4 incelendiğinde öğretmen adaylarının anlamayı sağlama kategorisinde en fazla birden çok duyu organına hitap etme ve ön bilgileri harekete geçirme tekniklerini kullandıkları görülmektedir. Slogan ve yazı tahtası kullanma teknikleri ise öğretmen adayları tarafından en az tercih edilen teknikler olmuştur.

Tablo 4'e göre kadın öğretmen adayları en fazla sırasıyla birden çok duyu organına hitap etme $(\% 30,64)$, ön bilgileri harekete geçirme $(\% 22,58)$, karşısındakini konuşmaya dâhil etme $(\% 20,96)$ ve açı, net, seviyeye uygun bir dil kullanma $(\% 20,96)$ tekniklerini; erkek öğretmen adayları ise sırasıyla en fazla açlk, net ve seviyeye uygun bir dil kullanma (\%35,71), ön bilgileri harekete geçirme $(\% 23,80)$ ile karşısındakini konuşmaya dâhil etme $(\% 19,66)$ tekniklerini kullanmışlardır. Kadın öğretmen adaylarının en az kullandıkları teknikler ise sırasıyla slogan $(\% 1,61)$ ve yazı tahtası kullanma $(\% 3,22)$ teknikleridir. Erkek öğretmen adaylarının en az kullandıkları teknikler de sırasıyla yazı tahtası kullanma $(\% 9,52)$ ve birden çok duyu organına hitap etme $(\% 14,28)$ teknikleridir. Ayrıca erkek öğretmen adaylarının slogan kullanma tekniğini hiç tercih etmemiş olmaları da dikkat çekici bir diğer bulgudur.

\footnotetext{
Adres $\mid$ Address

İstanbul Medeniyet Üniversitesi, Eğitim Bilimleri Fakültesi, Türkçe İstanbul Medeniyet University, Faculty of Education Sciences, ve Sosyal Bilimler Eğitimi Bölümü, Türkce Eğitimi ABD Cevizli Turkish and Social Scinces Education, Turkish Language Teaching Kampüsü, Kartal-İstanbul/TÜRKIYE $\quad$ Education, Cevizli Campus, Kartal-İstanbul /TURKEY e-posta: editor@rumelide.com 1 e-mail: editor@rumelide.com
} 


\begin{tabular}{|c|c|c|c|c|}
\hline \multirow{3}{*}{$\begin{array}{l}\text { ‘İnandırma' Basamağının } \\
\text { Alt Kategorileri }\end{array}$} & \multicolumn{4}{|c|}{ Cinsiyet } \\
\hline & \multicolumn{2}{|c|}{ Kadın } & \multicolumn{2}{|c|}{ Erkek } \\
\hline & $\mathbf{f}$ & $\%$ & $\mathbf{f}$ & $\%$ \\
\hline Empati kurma & 12 & 6,18 & 7 & 4,79 \\
\hline Ses tonu, vurgu ve tonlamayı etkin kullanma & 16 & 8,24 & 13 & 8,9 \\
\hline Hedef kitleye saygı duyma ve bunu gösterme & 20 & 10,3 & 12 & 8,21 \\
\hline Sayısal verilerden faydalanma & 16 & 8,24 & 9 & 6,16 \\
\hline Tanık gösterme/alıntı yapma & 3 & 1,54 & 8 & 5,47 \\
\hline Örnekler verme & 36 & 18,55 & 22 & 15,06 \\
\hline Abartılı açıklama/söz sanatları kullanma & 4 & 2,06 & - & - \\
\hline Mekânı etkin kullanma & 6 & 3,09 & 10 & 6,84 \\
\hline Olumlu sözcükler kullanma/pozitif olma & 18 & 9,27 & 14 & 9,58 \\
\hline Materyal kullanma & 20 & 10,3 & 9 & 6,16 \\
\hline Samimi ve içten bir üslup kullanma & 6 & 3,09 & 4 & 2,73 \\
\hline Zit fikirler sunma ve bunları çürütme & 3 & 1,54 & 5 & 3,42 \\
\hline Farklı çözüm önerileri sunma & 7 & 3,6 & 3 & 2,05 \\
\hline Mantıklı, nesnel argümanlar kullanma & 12 & 6,18 & 14 & 9,58 \\
\hline Karşılaştırma & 3 & 1,54 & 1 & 0,68 \\
\hline Jest, mimik ve beden dilini kullanma & 12 & 6,18 & 15 & 10,27 \\
\hline TOPLAM & 194 & & 146 & \\
\hline
\end{tabular}

Tablo 5: Öğretmen adaylarının 'inandırma' basamağında kullandıkları ikna tekniklerinin dağılımı

Tablo 5’e göre kadın öğretmen adayları tüm kategorilerde toplamda 194, erkek öğretmen adayları ise 146 teknik kullanmıştır. Bu sayısal üstünlük, kadınların oranının erkeklerden daha fazla olmasıyla ilişkilendirilebilir.

Tablo 5 incelendiğinde öğretmen adaylarının inandırma basamağında en fazla örnek(ler) verme, materyal kullanma ve pozitif olma/olumlu sözcükler kullanma tekniklerini kullandıkları görülmektedir. Karşılaştırma ve abartma/söz sanatları kullanma teknikleri ise öğretmen adayları tarafından en az tercih edilen teknikler olmuştur. 
Tablo 5’e göre kadın öğretmen adayları en fazla sırasıyla örnekler verme $(\% 18,55)$, materyal kullanma $(\% 10,3)$ ve pozitif olma/olumlu sözcükler kullanma $(\% 9,27)$ tekniklerini; erkek öğretmen adayları ise en fazla sirasiyla örnekler verme $(\% 15,06)$, jest, mimik ve beden dilini kullanma $(\% 10,27)$, pozitif olma/olumlu sözcükler kullanma $(\% 9,58)$ ve mantıklı/nesnel argümanlar kullanma $(\% 9,58)$ tekniklerini kullanmışlardır.

Kadın öğretmen adaylarının en az kullandıkları teknikler ise sırasıyla zit fikirler sunma $(\% 1,54)$ ve karşılaştırma $(\% 1,54)$ teknikleridir. Erkek öğretmen adaylarının en az kullandıkları teknikler de sırasıyla karşllaştırma $(\% 0,68)$ ve farklı çözüm önerileri sunma $(\% 2,05)$ teknikleridir. Ayrıca erkek öğretmen adayları abartılı açıklama/söz sanatları kullanma tekniğini hiç tercih etmemişlerdir.

Bunun yanı sıra erkek öğretmen adayları; zıt fikirler sunma ve bunları çürütme, mantıklı ve nesnel argümanlar kullanma, jest, mimik ve beden dilini kullanma, mekânı etkin kullanma ve tanık gösterme/alıntı yapma stratejilerinin kullanımında kadın adaylardan daha başarılı olmuşlardır. Kadın öğretmen adayları ise empati kurma; ses tonu, vurgu ve tonlamayı etkin kullanma, hedef kitleye saygı duyma ve bunu gösterme, sayısal verilerden faydalanma, örnekler verme, abartılı açıklama/söz sanatları kullanma, olumlu sözcükler kullanma/pozitif olma, materyal kullanma, samimi ve içten bir üslup kullanma, farklı çözüm önerileri sunma, karşılaştırma tekniklerinde erkek adaylara göre daha başarılı olmuşlardır.

\begin{tabular}{|c|c|c|c|c|}
\hline \multirow{3}{*}{$\begin{array}{l}\text { 'Tekrarlama ve isteneni açıklama' Basamağının Alt } \\
\text { Kategorileri }\end{array}$} & \multicolumn{4}{|c|}{ Cinsiyet } \\
\hline & \multicolumn{2}{|c|}{ Kadın } & \multicolumn{2}{|c|}{ Erkek } \\
\hline & $\mathbf{f}$ & $\%$ & $\mathbf{f}$ & $\%$ \\
\hline Net ve kesin ifadeler kullanma & 13 & 21,31 & 14 & 28,57 \\
\hline Mesajı ve anahtar kelimeleri tekrarlama & 18 & 29,5 & 10 & 51,02 \\
\hline Süreyi verimli/etkin kullanma & 20 & 32,78 & 16 & 81,63 \\
\hline Özetleme & 11 & 18,03 & 9 & 18,63 \\
\hline TOPLAM & 61 & & 49 & \\
\hline
\end{tabular}

Tablo 6: Öğretmen adaylarının ‘tekrarlama ve isteneni açıklama' basamağında kullandıkları ikna tekniklerinin dağılımı

Tablo 6 incelendiğinde kadın ve erkek öğretmen adayları, tekrarlama ve isteneni açılama basamağında en fazla 'süreyi verimli kullanma' tekniğini tercih etmişlerdir. Kadın öğretmen adayları tüm kategorilerde toplamda 61, erkek öğretmen adayları ise 49 teknik kullanmıştır. Bu sayısal üstünlük kadınların oranının erkeklerden daha fazla olmasıyla ilişkilendirilebilir.

Tablo 6'ya göre kadın ve erkek öğretmen adayları tarafından en az kullanılan teknik, özetleme (kadın \%25,49, erkek \%18,63) tekniğidir. Net ve kesin ifadeler kullanma tekniği daha çok erkek öğretmen adayları tarafından $(\% 28,57)$; mesajı ve anahtar kelimeleri tekrarlama tekniği ise en çok kadın öğretmen adayları tarafından $(\% 29,5)$ kullanılmıştır. 
Persuasion techniques used by Turkish teacher candidates in their persuasive speeches in terms of speaking education / E. Aktaş (pp. 180-197)

\section{Sonuç ve tartışma}

Dört temel dil becerisinden biri olan konuşma, öğretmen adaylarının en çok zorlandıkları öğrenme alanlarından biridir (Ayan, Katrancı ve Melanlıŏlu, 2014). Akyol’a göre de (2006) öğrenciler en çok ikna edici metin türü oluşturmada zorluk yaşamaktadırlar. Bu becerinin geliştirilmesi için farklı yöntem ve tekniklerin uygulamalı bir şekilde öğrencilere kazandırılması gerekmektedir. İkna edici metin üretebilme becerisi öğrencilerin akademik yaşantıları için büyük önem taşımaktadır (Crowhurst, 1990'dan akt. Esmer, 2018: 208). Nitekim Yangil ve Ünal (2019) ikna etme tekniğiyle işlenen derslerin Türkçe öğretmeni adaylarının konuşma tutumunu olumlu yönde etkilediğini tespit etmişlerdir.

$\mathrm{Bu}$ araştırmanın sonucunda, öğretmen adaylarının ikna edici konuşmanın dikkat çekme ile inandırma kategorilerinde diğer iki kategoriye göre daha başarılı oldukları tespit edilmiştir. Buna göre öğretmen adaylarının dikkat çekme etkinlikleri kapsamında; soru sorma, örnekler verme, içerikten haberdar etme, görsellerden faydalanma, ses tonunu etkin kullanma vb. tekniklerini daha sık kullandıkları görülmektedir. İnandırma etkinlikleri kapsamında ise örnekler verme, materyal kullanma, pozitif olma, ses tonu/vurgu ve tonlamayı etkin kullanma, sayısal verilerden yararlanma stratejilerini sıkça tercih ettikleri ifade edilebilir.

Alıcının ikna olmasını sağlayan tekniklerden biri, merak uyandırmaktır. Beklenmedik bilgi ve iddialar ortaya atmak, dikkati çekmeye yarar ve bu dikkat sayesinde alıcının konuyu benimsemesi de daha kolay olur (Hogan ve Speakman, 2012; Deniz, 2011: 625). Bu araştırmada da merak uyandırma tekniğinin kullanımı açısından kadın öğretmen adayları $(\% 25,62)$ erkeklerden $(\% 37,2)$ daha başarılı olmuşlardır. Bununla birlikte bu tekniğin kullanımı açısından her iki cinsiyet açısından da başarılı elde edildiği söylenebilir.

Bilimsel kantt kullanma, ikna edici iletişimdeki en önemli tekniklerden biridir. Akla ve mantığa uygun sayısal veriler, rapor, alıntı, tanık gösterme, tarih verme, bilimsel kıyaslama gibi kanıtlar alıcının ikna olması için ciddi bir etki yaratmaktadır. Aynı zamanda mesajlardaki bilimsel kanıtlar, dinleyicileri gerçekçi düşünmeye de sevk etmektedir (Deniz, 2011: 619). Ayrıca mesajda zitlıklardan yararlanma, insanların karşlaştırmalar yapmalarına olanak sağlar. Karşlaştırma yapan insanlar konu üzerinde düşünme ve karar verme eğilimindedir (Hogan ve Speakman, 2012). Bu araştırmada da öğretmen adaylarının karşıdakini ikna etmek için sayısal verilerden yararlanma, karşılaştırma, tanık gösterme ve örnek verme tekniklerini kullandıkları tespit edilmiştir. Bununla birlikte kadın öğretmen adaylarının erkeklerden daha fazla teknik kullandığı da tespit edilmiştir. Bu sonuca benzer olarak Kurudayığlu da (2011) sözlü anlatım becerilerinde kadın öğretmen adaylarının erkek adaylardan daha fazla düşünceyi geliştirme tekniği kullandığını tespit etmiştir.

Olayları karşıdaki insanın gözünden görme yani empati kurma, ikna edici iletişimde önemli bir adımdır (Hogan ve Speakman, 2012: 46). Empati, alıcıyı etkileme gücünü artırır. Kişinin empati yeteneğinden mahrum olması, ikna girişimini başarısız kılan en önemli faktörlerdendir (Deniz, 2011: 622). Bu araştırmada da kadın öğretmen adayları empati kurma konusunda erkek adaylardan daha başarılı olmuşlardır. Bu sonuca benzer şekilde yapılan bazı araştırmalar, kadınların empati kurma noktasında erkeklerden daha başarılı olduğunu ortaya koymaktadır (Yüksel, 2004; Çarıkçı ve Atilla, 2009; Arslan, 2016).

Hedef kitleye saygı duyma ve bunu belli etme, ikna edici iletişimin en önemli boyutlarından biridir. Bir kişiye saygı göstermeden onu ikna etmeye çalışmak oldukça zordur. Birey, kendisine saygı

\footnotetext{
Adres $\mid$ Address

İstanbul Medeniyet Üniversitesi, Eğitim Bilimleri Fakültesi, Türkçe İstanbul Medeniyet University, Faculty of Education Sciences, ve Sosyal Bilimler Eğitimi Bölümü, Türkçe Eğitimi ABD Cevizli Turkish and Social Scinces Education, Turkish Language Teaching Kampüsü, Kartal-İstanbul/TÜRKIYE $\quad$ Education, Cevizli Campus, Kartal-İstanbul /TURKEY e-posta: editor@rumelide.com 1 e-mail: editor@rumelide.com
} 
gösterildiğinde daha kolay ikna olur (Hogan ve Speakman, 2012). Bu araştırmada da kadın öğretmen adayları hedef kitleye saygı duyma tekniğini erkeklerden daha fazla kullanarak daha başarılı bir ikna edici konuşma performansı sergilemişlerdir.

Deniz’e (2011) göre net ve kesin ifadeler kullanmak, kendinden emin olmanın ve karşı tarafı ikna etmenin en güzel yollarındandır. Konuşmada dinleyicilerin ilgisini ve dikkatini dağıtacak uzun cümleler kurmak, anlaşılmayı zorlaştırır. Bunun yerine kısa, net, anlaşılır ve akıcı cümleler tercih edilmelidir (Tellioğlu, 2002: 74). Bu, aynı zamanda insanları ikna etmeyi kolaylaştırır. Bu araştırmada da net ve kesin ifadeler kullanma noktasında erkek ve kadın öğretmen adayları eşit düzeyde başarı göstermişlerdir.

Zamanı etkili kullanmak ikna edici iletişimde önemli bir unsurdur. Özellikle süreyi dinleyicinin sabrını zorlayacak kadar uzun kullanmak, ikna olmayı engelleyici bir durum ortaya çıkarabilir (Deniz, 2011). $\mathrm{Bu}$ araştırmada da süreyi verimli/etkin kullanma noktasında genel olarak öğretmen adaylarının başarılı oldukları söylenebilir. Erkek öğretmen adaylarının süreyi etkin kullanma noktasında kadın adaylardan daha başarılı oldukları da dikkat çeken başka bir sonuçtur.

İkna etmenin etkili yollarından biri de hedef kitlenin ilgi, yaş, cinsiyet vb. özelliklerine uygun örnekler vermek, açıklamalar yapmak ve kelime hazinesi seçmektir. Kurudayığlu ve Yılmaz (2014) da öğrencilerin ikna etme tekniklerini ve türlerini bilmesi gerektiğini, çünkü okul yaşamında ve günlük hayatta pek çok ikna çeşidiyle yüzleştiklerini belirtmektedirler. Bu doğrultuda öğretmen adaylarının hedef kitlenin yaş, eğitim ve cinsiyet özelliklerine uygun bir konuşma tasarlamada kısmen başarılı oldukları ifade edilebilir. Bu sonucun aksine Deniz (2007), öğretmenlerin ikna tekniklerini sınıf içi iletişimde öğrenci seviyesine ve beklentisine uygun olarak yansıtamadıklarını tespit etmiştir.

$\mathrm{Bu}$ çalışmada öğretmen adayları anlamayı sağlama ile tekrarlama/isteneni açıklama basamaklarında kısmen daha başarısız olmuşlardır. Buna göre öğretmen adayları anlamayı sağlama etkinlikleri kapsamında, birden çok duyu organına hitap etme ile ön bilgileri harekete geçirme tekniklerini daha sık kullanmışladır. Karşıdaki kişiyi ikna etmeyi kolaylaştıran etkenlerden biri onunla ilgili ön bilgilere sahip olmaktır. Bu ilke, yapılandırmacı yaklaşımın da temel özelliklerinden biridir. Öğretmenlerin öğrenme-ö̆gretme sürecini planlarken öğrencilerin kişilik özelliklerinden öğrenme stillerine kadar pek çok hususu göz önünde bulundurması gerekmektedir.

Tekrarlama ve isteneni açıklama, ikna edici bir konuşmanın son aşamasıdır. Buna göre öğretmen adayları bu aşamada, süreyi verimli kullanma ve mesajı tekrar etme tekniklerini daha çok kullanmışlardır. Bununla birlikte bu aşamada öğretmen adaylarının özetleme stratejisini çok az tercih ettikleri tespit edilmiştir. Oysa özetleme, ikna edici bir konuşmayı bitirmeden önce başvurulması gereken önemli bir stratejidir. Etkili iletişimde ve iknada mesajı tekrar etmenin büyük etkisi vardır. Mesajın tekrar edilmesi konunun daha iyi anlaşılmasına ve kalıcılığa katkı sağlar. Özellikle konuşma esnasında tekrar tekniğini kullanmak, bir bakıma zorunluluktur. Çünkü yazılı bir metinde okuyucunun geri dönüp eksik bilgilerini tamamlaması olasıdır ancak dinlemede böyle bir durum söz konusu değildir. Bu nedenle konuşmacı, karşıdakini ikna etme sürecinde önemli noktaları tekrar ederek ikna sürecini kolaylaştırmalıdır (Deniz, 2011: 608). Bu araştırmada da kadın öğretmen adaylarının tekrar tekniğini kullanmada kısmen daha başarılı oldukları tespit edilmiştir.

Bu çalışmada ikna tekniklerinin kullanımının cinsiyet değişkeni açısından farklılaştığı tespit edilmiştir. Buna göre tüm ikna tekniklerinin kullanımı açısından kadın öğretmen adayları erkeklerden daha

Adres

İstanbul Medeniyet Üniversitesi, Eğitim Bilimleri Fakültesi, Türkçe ve Sosyal Bilimler Eğitimi Bölümü, Türkçe Eğitimi ABD Cevizli Kampüsü, Kartal-İstanbul/TÜRKIYE e-posta: editor@rumelide.com 
başarılı olmuşlardır. Bu durum, kadın öğrenci oranının fazla olmasıyla açıklanabilir. Ancak yine de kadınların ikna tekniklerini kullanmada erkeklere göre daha başarılı oldukları söylenebilir. Bu sonuca benzer olarak Deniz (2007)'in yaptığı çalışmada da ikna becerileri ve tekniklerini uygulama konusunda kadın öğretmenlerin, erkek meslektaşlarına göre daha ileri düzeyde olduğu tespit edilmiştir. Öner de (1999) araştırmasında sınıf ve okul içi iletişimde kadın öğretmenlerin erkek meslektaşlarından daha etkili olduğu, daha iyi iletişim kurduğu ve öğrenciler tarafından daha çok sevildiğini ortaya koymuştur.

$\mathrm{Bu}$ araştırmada kadın öğretmen adaylarının en çok dikkat çekme ve inandırma basamağında ikna tekniği kullandıkları tespit edilmiştir. Benzer şekilde erkek öğretmen adayları da en çok tekniği dikkat çekme ve inandırma basamağında kullanmışlardır. Tekrarlama ve isteneni açıklama basamağında ise her iki cinsiyet de başarılı olamamıştır.

Kadın öğretmen adayları dikkat çekme basamağında en çok örnekler verme ve soru sorma tekniklerini tercih etmişlerdir. Erkek öğretmen adayları ise soru sorma tekniğini kadınlardan daha çok tercih etmiştir. Teknolojiden faydalanma tekniğinde ise erkek öğretmen adayları kadınlardan daha başarılı olmuştur. Müzik ve görsellerden faydalanma tekniklerinde ise yine kadın öğretmen adayları erkeklerden daha başarılı olmuşlardır. Bununla birlikte jest, mimik ve beden dili ile ses tonunu etkin kullanma teknikleri her iki cinsiyet açısından da orta düzeyde kalmıştır. Bu sonuca benzer şekilde Göçer ve Akgül (2019) çalışmalarında Türkçe öğretmenlerinin öğrenme-öğretme sürecinde etkileşimli tahtadan ve eğitsel oyunlardan, afis, poster gibi görsel materyallerden, hikâye, roman, şiir metin türlerinden, doğaçlama ve münazara tekniklerden sıklıkla faydalandıklarını tespit etmişlerdir.

Kadın öğretmen adayları anlamayı sağlama basamağında en çok birden fazla duyu organına hitap etme tekniğini kullanmışlardır. Bu sonucun aksine erkek adaylar; açık, net ve seviyeye uygun bir dil kullanma konusunda kadınlardan daha başarılı olmuşlardır. Her iki teknik de karşıdakini ikna etmek için anlamayı sağlama aşamasında gerekli olan tekniklerdir. Yazı tahtasını kullanma tekniği ise erkek öğretmen adayları tarafından daha çok tercih edilmiştir. Bu, dikkat çekici bir sonuçtur. Bu aşamada slogan kullanma tekniği ise tek bir kadın öğretmen adayı tarafından tercih edilmiştir. Bunun dışında hiçbir öğretmen adayı bu tekniği kullanmamıştır.

İkna edici bir konuşmanın en önemli aşaması inandırma aşamasıdır. Bu çalışmada, kadın öğretmen adaylarının erkeklerden daha fazla teknik kullandığı dolayısıyla daha başarılı olduğu söylenebilir. Bununla birlikte kadın adaylar, örnek verme ve materyal kullanma tekniklerini daha fazla tercih etmişlerdir. İkna sürecinde örnekler vermek, kaynağa olan güveni de artıran bir durumdur. Örnekler aynı zamanda kaynağa olan güveni artırmaktadır (Deniz, 2011: 623). Hogan ve Speakman (2012: 171) ikna edici iletişimde dinleyenlere bir hikâye veya anekdot aracıllğıyla değer, tutum ve inanç aktarılabileceğini belirtmektedir. Mekânı etkin kullanma açısından da erkek öğretmen adaylar, kadınlara göre daha başarılı olmuşlardır. Buna göre konuşma yapılan sınıf ortamını gezme, öğrencilerle yakın olma ikna açısından önemli bir durumdur. Yine araştırmaya göre zıt fikirler sunarak bunları çürütme ve mantıklı, nesnel argümanlar kullanma erkek öğretmen adaylarının daha çok tercih ettiği teknikler olmuştur. Ayrıca jest, mimik ve beden dilini etkin kullanmada da erkek öğretmen adaylarının daha başarılı olduğu göze çarpmaktadır.

Tekrarlama ve istenileni açıklama basamağı, ikna edici bir konuşmanın en son aşamasıdır. $\mathrm{Bu}$ aşamada özellikle süreyi etkin kullanma önemlidir. Çünkü ne kadar etkili bir sunum yapılırsa yapılsın son sözü söylemeden süreç tamamlanmaz. Bu aşamada her iki cinsiyet grubunda yer alan öğretmenlerin kısmen başarılı oldukları söylenebilir. Ancak araştırmanın sonuçlarına göre her iki

Adres 
cinsiyet de özetleme tekniğini kullanmada başarılı olamamıştır. Oysa Deniz’e göre (2011: 605) mesajların peş peşe sözlü olarak sunulduğu durumlarda alıcının ilgisi dağılır. Bunun önüne geçmek için de konuşmacı, arada ve sonda özet yaparak ilgiyi toplamalıdır.

İlgili literatür tarandığında öğrencilerin ikna edici konuşma becerilerini çeşitli yönleriyle değerlendiren bir çalışmaya rastlanmamıştır. Çalışmalar, çoğunlukla ikna edici yazma becerisini incelemeye yöneliktir. Bu araș,tırmalar, farklı yas, ve seviyelerde olan öğrencilerin ikna edici metin olușturma becerilerinin istenen düzeyde olmadığını ortaya koymaktadır. Kan ve Erbaş (2017) ile Kaptan (2015) da çalışmalarında beşinci sınıf öğrencilerinin ikna edici yazma becerilerinin istenilen seviyede olmadığını tespit etmişlerdir. Benzer şekilde, Kurudayığlu ve Yılmaz (2014) da Türkçe öğretmeni adaylarının oluşturdukları ikna edici metinlerin yeterli düzeyde olmadığını belirlemişlerdir.

\section{Öneriler}

Türkçe öğretmeni adaylarının ikna edici konuşmalarında kullandıkları ikna tekniklerinin incelendiği bu araştırmada, ikna edici konuşma becerilerinin uygulama ve etkinliklerle geliştirilebileceği düşünülmektedir. Araştırma sonucunda aşağıdaki öneriler getirilebilir:

İkna; hem bir konuşma ve yazma tekniği hem de öğrenme şeklidir. Diğer konuşma tekniklerinden farklı olarak iknanın yarattığı etki büyüktür. Çünkü iletişim, temelde karşıdakini ikna etmeye dayalı bir süreçtir. Bu nedenle ikna edici konuşma, özelikle ilköğretimden itibaren öğrencilere çeşitli etkinlikler yoluyla kazandırılmalıdır. Bunun için uygulamalı konuşma etkinlikleri yaptırılmalıdır.

İkna etme, ilköğretimde bir yazı ve konuşma tekniği olarak karşımıza çıkmaktadır. Dolayısıyla öğretmen adaylarının ikna tekniklerini iyi bilmesi, bunları öğrencilerine öğretmesi açısından da önemlidir. İkna edici konuşmada başarılı olmak için ikna tekniklerini bilmek gereklidir. Bu çalışmada ilgili literatür taranarak ortaya konan ikna tekniklerinden konuşma eğitiminde faydalanılabilir.

Öğretmen adaylarının ya da ilköğretim düzeyindeki öğrencilerin ikna edici konuşma becerisi ile ilgili deneyimlerini, görüşlerini ortaya çıkarmaya dönük nitel çalışmalar yapılabilir. Böylelikle eksiklikler, sorunlar belirlenip yapılması gerekenler için önlem alınabilir.

$\mathrm{Bu}$ araştırma öğretmen adaylarının ikna edici konuşma becerilerini betimlemeye yöneliktir. Ders kitapları ve öğretim programındaki ikna edici konuşma kazanım ve etkinliklerini ortaya çıkaran betimleyici çalışmalar yapılabilir.

Rol yapma, drama, tartışma, münazara gibi konuşma yöntemlerinin ikna edici konuşmayı geliştirip geliştirmediğine yönelik deneysel çalışmalar yapılabilir.

\section{Kaynakça}

Akyol, H. (2006). Yeni programa uygun Türkçe öğretim yöntemleri. Ankara: Kök.

Arslan, Y. (2016). Kim daha iyi empati kuruyor -empati üzerine mikro bir sosyolojik araştırma-. Yaşam Bilimleri Dergisi, 6 (2/1), 51-64.

Ayan, S., Katrancı, M. ve Melanlıoğlu, D. (2014). Awareness level of teacher candidates' in terms of their Turkish language sufficiency: A qualitative research. International Journal of Academic Research Part B, 6 (29), 137-143.

Beyreli, L. ve Konuk, S. (2018). Altıncı sınıf öğrencilerinin ikna edici yazma becerisinin geliştirilmesine yönelik bir araştırma. Ĕgitim ve Bilim, 43 (193), 181-215.

\footnotetext{
Adres $\mid$ Address

İstanbul Medeniyet Üniversitesi, Eğitim Bilimleri Fakültesi, Türkçe ve Sosyal Bilimler Eğitimi Bölümü, Türkce Eğitimi ABD Cevizli Turkish and Social Scinces Education, Turkish Language Teaching Kampüsü, Kartal-İstanbul/TÜRKIYY $\quad$ Education, Cevizli Campus, Kartal-İstanbul /TURKEY e-posta: editor@rumelide.com 1 e-mail: editor@rumelide.com
} 
Persuasion techniques used by Turkish teacher candidates in their persuasive speeches in terms of speaking education / E. Aktaş (pp. 180-197)

Çarıkçı, I. H. ve Atilla, G. (2009). Erillik/dişilik boyutunun empatik beceri ile ilişkisi. Uluslararası Alanya İşletme Fakültesi Dergisi, 1(2), 52.63.

Demirtaş, H. A. (2004). Temel ikna teknikleri: tutum oluşturma ve tutum değiştirme süreçlerindeki etkilerinin altında yatan nedenleri üzerine bir derleme. Gazi Üniversitesi İletişim Fakültesi Dergisi, 19, 73-91.

Deniz, K. (2007). İlköğretim ikinci kademede konuşma ve dinleme yoluyla öğrencileri ikna üzerine bir araştırma. Yayımlanmamış Doktora Tezi, Ankara: Gazi Üniversitesi Eğitim Bilimleri Enstitüsü.

Deniz, K. (2011). Etkili iletişim. Salih Gülerer (Ed.), Üniversiteler için dil ve anlatım içinde (ss. 549635). Ankara: Gazi.

Dökmen, Ü. (1995). İletişim çatışmaları ve empati. İstanbul: Sistem.

Ergin, A. ve Birol, C. (2000). Eğitimde iletişim. Ankara: Anı.

Esmer, E. (2018). Türkçeyi yabancı dil olarak öğrenen öğrenciler tarafından üretilen ikna metinlerinde üst söylem belirleyicilerinin kullanımı. Dil Eğitimi ve Araştırmaları Dergisi, 4 (3), 216-228.

Göçer, A. ve Akgül, O. (2019). Türkçe öğretmenlerinin dil eğitiminde ortam tasarımı ve materyal kullanımı yeterliklerinin değerlendirilmesi. Bingöl Üniversitesi Sosyal Bilimler Enstitüsü Dergisi, 18 (9), 837-855.

Hogan, K. (2007). Başkaların sizin gibi düşündürmeye nasıl ikna edersiniz? İkna etmenin psikolojisi. (Çev.: T. S. Güneş, E. Karanimoğlu). İstanbul: Yakamoz.

Hogan, K. ve Speakman, J. (2012). Gizli ikna taktikleri. T. Gezer (Çev.). İstanbul: Yakamoz.

Kağıtçıbaşı, Ç. (2005). Yeni insan ve insanlar. (10. Baskı). İstanbul: Evrim.

Kan, M. O. ve Erbaş, A. (2017). Beşinci sınıf öğrencilerinin ikna edici yazma becerilerinin çeşitli değişkenler açısından incelenmesi. İnsan ve Toplum Bilimleri Araştırmaları Dergisi, 6 (5), 22282246.

Kaptan, A. (2015). İlköğretim beşinci sımf öğrencilerinin ikna edici yazma beceri düzeylerinin belirlenmesi. Yayımlanmamış Yüksek Lisans Tezi, Eskişehir: Osmangazi Üniversitesi.

Kurudayığlu, M. (2011). Türkçe öğretmeni adaylarının sözlü anlatımlarının düşünceyi geliştirme teknikleri açısından incelenmesi. TÜBAR, XXIX, 213-226.

Kurudayığlu, M. ve Yılmaz, E. (2014). Nasıl ikna ediliyoruz? İkna edici metin ve yapısı. Eğitimde Kuram ve Uygulama, 10 (1), 75-102. https://dergipark.org.tr/tr/pub/eku/issue/5459/74060.

MEB. (2009). İlköğretim Türkçe dersi öğretim programı ve kılavuzu (1-5. Sınıflar), Ankara: MEB

MEB. (2006). İlköğretim Türkçe (6, 7, 8. Sınıf) Dersi Öğretim Programı, MEB: Ankara.

MEB. (2019). Türkçe dersi öğretim programı 1-8. Simıflar. Ankara: MEB.

Merriam, S. B. (2013). Nitel araştırma desen ve uygulama için bir rehber. (Çev. Ed.: S. Turan), Ankara: Nobel.

Miles, M, B. and Huberman, A. M. (1994). Qualitative data analysis: An expanded sourcebook. Thousand Oaks, CA: Sage.

Mutlu, E. (1994). İletişim sözlüğ̈̈. Ankara: Ark.

NCFCA. (2012). Persuasive Speaking Rules, National Christian Forensics and Communications Association: ABD.

Okur, A., Göçen, G. ve Süğümlü, Ü. (2013). İkna edici yazma ve karşlaştırmalı bir araştırma (Avustralya ana dili öğretimi ders materyalleri ve Türkiye örneği). Mustafa Kemal Üniversitesi Sosyal Bilimler Enstitüsü Dergisi, 10 (21), 167-197.

Öner, M. (1999). İlköğretim okulları 1. kademe öğretmenlerinin sınıfta iletişimi sağlama etkinlikleri. Yayımlanmamış Yüksek Lisans Tezi. Marmara Üniversitesi, Fen Bilimleri Enstitüsü, İstanbul.

\footnotetext{
Adres $\mid$ Address

İstanbul Medeniyet Üniversitesi, Eğitim Bilimleri Fakültesi, Türkçe İstanbul Medeniyet University, Faculty of Education Sciences, ve Sosyal Bilimler Eğitimi Bölümü, Türkce Eğitimi ABD Cevizli Turkish and Social Scinces Education, Turkish Language Teaching Kampüsü, Kartal-İstanbul/TÜRKIYE $\quad$ Education, Cevizli Campus, Kartal-İstanbul /TURKEY e-posta: editor@rumelide.com 1 e-mail: editor@rumelide.com
} 
Patton, M. Q. (2014). Nitel araştırma ve değerlendirme yöntemleri. (Çev. Ed.: M. Bütün ve S. B. Demir), Ankara: PegemA.

Senemoğlu, N. (1997). Gelişim öğrenme ve öğretim kuramdan uygulamaya. Ankara: Gazi.

TDK (2011). Türkçe sözlük. Ankara: TDK.

Tellioğlu, C. (2002). Güzel konuşma pratiği. İstanbul: Timaş.

Tutar, H. ve Yılmaz, M. K. (2003). Genel iletişim. (3. Baskı). Ankara: Nobel.

Türkkan, R. O. (2000). İkna ve uzlaşma sanatı. (3. Baskı). İstanbul: Hayat.

Yangil, M. K. ve Topçuoğlu Ünal, F. (2019). İkna etme tekniğinin konuşma tutumu üzerindeki etkisi. Ana Dili Eğitimi Dergisi, 7 (2), 321-336.

Yıldırım, A. ve Şimşek, H. (2016). Sosyal bilimlerde nitel araştırma. Ankara: Seçkin.

Yüksel, A. (2004). Empati eğitim programının ilköğretim öğrencilerinin empatik becerilerine etkisi. Uludă̆ Üniversitesi Eğitim Fakültesi Dergisi, 17(2), 341-354.

Yüksel, A. H. (1994). İkna edici iletişim. Eskişehir: Anadolu Üniversitesi.

Yüksel, A. H. (2005). İkna ve konuşma. Eskişehir: Anadolu Üniversitesi.

Yüksel, A. H. (2019). Etkileme, etkili iletişim ve ikna edici konuşma. Etkili iletişim teknikleri içinde (Ed.: E. Eroğlu, A. H. Yüksel), ss. 145-179. Eskişehir: Anadolu Üniversitesi. 